\title{
PENERAPAN CUSTOMER RELATIONSHIP MANAGEMENT PADA SISTEM INFORMASI PEMESANAN DAN PENJUALAN PADA TOKO BUKU GAPURA BERBASIS WEB
}

\author{
${ }^{1}$ Cosmas Tambunan, ${ }^{2}$ Darwis Robinson Manalu, ${ }^{3}$ Jimmy F. Naibaho \\ Sistem Informasi, Fakultas Ilmu Komputer, Universitas Methodist Indonesia \\ cosmastbn@gmail.com ${ }^{1}$, manaludarwis@gmail.com², jimmyfebrian@gmail.com ${ }^{3}$
}

\begin{abstract}
The use of technology in the application of Customer Relationship Management (CRM) becomes very important to build relationships between customers as well as providing information provided to customers. The benefits of implementing CRM are to help keep existing customers and to gain new customers. In this study the authors implement CRM in an information system E-commers on Bookstore Gapura. Where currently there is no E-commission information system available in Gapura Bookstore. The method used in this design is using Data Flow Diagram (DFD). This application is also created by using PHP programming language using MySQL. With this application so that facilitate Bookstore Gapura in providing information and promotion, so that information delivered more efficient and clear to the consumer.
\end{abstract}

Keywords: Information System, Sales, CRM, Book Store Gapura

\section{I.PENDAHULUAN}

Saat ini perkembangan teknologi sudah sangat pesat dalam membantu kegiatan sebuah perusahaan atau organisasi, namun masih ada juga perusahaan yang masih belum memanfaatkan menggunakan perkembangan teknologi informasi. Akibatnya proses kinerja perusahaan atau organisasi tersebut berjalan kurang efektif dan efisien.

Sebagai toko buku yang menjual berbagai jenis buku, proses penjualan dan pemesanan masih dilakukan dengan cara manual, dimana hal tersebut memerlukan proses dan waktu yang tidak efisien sehingga mengakibatkan perusahaan kurang berjalan efektif. Guna meningkatkan kegiatan perusahaan dan pelayanan, di perlukan sistem informasi pemesanan dan penjualan yang mampu memberikan layanan yang efisien dan cepat kepada pelanggan.

Untuk mengatasi masalah ini maka membuat "sistem informasi pemesanan dan penjualan berbasis Web dengan menerapkan customers relationship management di dalamnya".

\section{TINJAUAN PUSTAKA}

A. Pengertian Sistem Informasi Berbasis Web

Sistem Informasi Berbasis Web adalah suatu sistem informasi yang menggunakan teknologi web atau internet untuk memberikan informasi atau layanan Kepada pengguna.

Sebuah sistem informasi berbasis web biasanya terdiri dari satu atau lebih aplikasi web yang masing- masing komponen mempunyai fungsi tertentu. Dimana masing - masing komponen tersebut saling mendukung satu sama lain guna mencapai fungsi sistem informasi berbasis Web secara umum.

B. Komponen Pada Web

Komponen yang harus ada dalam sebuah website sehingga sehingga situs tersebut dapat onine dan berfungsi dengan baik. Berikut adalah komponenkomponen website:

\section{A. Domain}

Domain adalah nama unik yang diberikan untuk mengidentifikasi alamat (IP address) server komputer seperti web server di internet. Domain memberikan kemudahaan pengguna internet untuk melakukan akses ke server dan memudahkan mengingat server yang dikunjungi dibandingkan harus mem=ngingat sederean angka-angka IP addres.

\section{B. Hosting}

Hosting adalah space harddisk dalam komputer server yang digunakan untuk penyimpanan database, email dan file web.

\section{Server Web}

Server web adalah perangkat lunak yang menyediakan layanan akses kepada pengguna melalui protokol komunikasi HTTP atau HTTPS atas berkas-berkas yang terdapat pada suatu situs web dalam layanan ke pengguna dengan menggunakan aplikasi tertentu seperti peramban web.

\section{CPANEL}

Cpanel adalah kontrol panel terproteksi. Fasilitas ini memudahkan pemilik account hosting untuk mengatur seluruh fasilitas web hosting yang dimilikinya. Fasilitas itu antara lain Menciptakan email forwarder, membuat atau menghapus nama/user database MySQL, Upload file website dan database,mengatur konfigurasi PHP.

\section{Penegrtian Customer Relationship Management}

CRM (Customer Relationship Management) merupakan strategi bisnis dengan menggunakan teknologi informasi menyediakan suatu usaha menyeluruh pada pelanggan yang terintegrasi untuk mempertahankan serta memperluas manfaat hubungan. (Imam Husni, 2014). Proses Customer Relationship Management (CRM), adalah mengumpulkan data pelanggan, menganalisi data dan identitas target pelanggan, mengembangkan program CRM, dan mengimplementasikan program CRM. Dalam hal ini perusahaan menggunakan strategi Cusomer Relationship Management (CRM) dengan tujuan agar perusahaan tetap fokus terhadap pelanggan berdasarkan informasi atau basis data (database) pelanggan yang dimiliki.

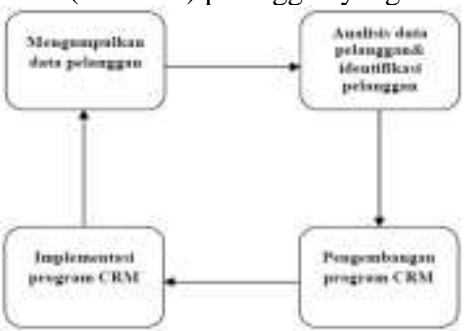

Gambar 1 Proses CRM 


\section{ANALISA DAN PERANCANGAN SISTEM}

1. Analisis digunakan untuk mengidentifikasi permasalahan yang ada dan mencari penyebabnya. Berikut ini adalah tahap-tahap analisis permasalahan yang dilakukan, yaitu:

a. Belum tersedianya alternatif media penghubung antara perusahaan dengan pelanggan dalam penyampaian berita dan informasi produk yang di jual, serta penerimaan kritik dan saran dari pelanggan.

b. Belum adanya sistem khusus yang dapat menyimpan semua data dan informasi produk yang ada pada Toko Buku Gapura tersebut. .

c. Belum adanya media komunikasi alternatif yang digunakan untuk melakukan pemesanan buku maupun informasi layanan baru yang lebih cepat.

2. Perancangan Sistem

Rancangan Aplikasi Customer Relationship Management ini untuk membangun loyalitas kepada pelanggan pada Toko Buku Gapura telah memenuhi tahap CRM sehingga dapat mengelola data pelanggan, promosi produk, data permintaan produk dan status pesanan pelanggan. Implementasi strategi CRM ini diharapkan Toko Buku Gapura mengenal pelanggannya dengan baik dan meningkatkan pelayanan pada pelanggannya. Toko Buku Gapura dapat memantau keluhan pelanggan dan menindak lanjuti permasalahan dari setiap pelanggan dengan cepat dalam rangka menciptakan hubungan baik dengan para pelanggan lebih dari sekedar transaksi.

Fitur-fitur website Customer Relationship Management pada Toko Buku Gapura adalah sebagai berikut:

1. Pemesanan Online

Pelanggan dapat melakukan pemesanan secara online dengan menggunakan website ini, dengan input data secara pribadi dapat mengurangi terjadinya kesalahan input dan memudahkan admin untuk melakukan pemeriksaan.

2. History Transaksi

Adanya fitur history berfungsi untuk membantu perusahaan maupun konsumen melihat transaksi yang telah terjadi.

3. Customer Service

Fitur ini digunakan untuk meningkatkan kualitas hubungan dengan konsumen. Konsumen dapat secara langsung memberikan saran maupun melaporkan adanya keluhan atas kurang nyamannya pelayanan yang diberikan, sehingga perusahaan dapat mencari penyelesaian masalah tersebut dan dapat meningkatkan pelayanan.

4. Event/Promo

Fitur ini berfungsi untuk memberikan informasi berupa event potongan harga kepada konsumen.

5. Live Chat

Fitur ini memudahkan konsumen berkomunikasi secara langsung pada saat bersamaan dengan pihak toko buku gapura. Fitur ini dapat meningkatkan layanan konsumen.

\section{Data Flow Diagram}

Data Flow Diagram (DFD) merupakan suatu model proses yang dibuat untuk menggambarkan darimana asal data, dan kemana tujuan data yang keluar dari sistem, dimana data disimpan, proses apa yang menghasilkan data tersebut. (Rita Afyenni, 2014)

DFD memungkinkan untuk menggambarkan sistem dari level yang paling tinggi kemudian menguraikannya menjadi level yang lebih rendah (dekomposisi). Berikut ini adalah gambar Diagram Nol yang telah dibangun seperti yang terlihat pada 4.1 di bawah ini :

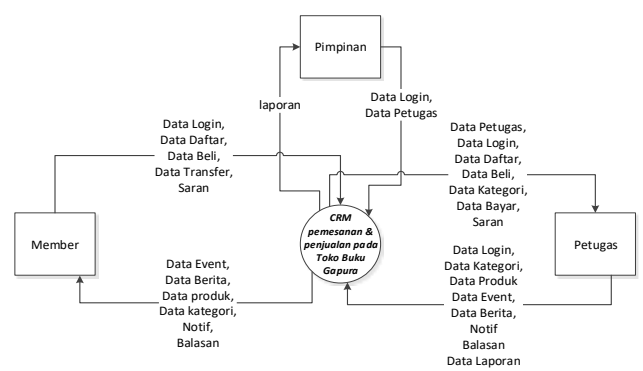

Gambar 2 Diagram Konteks Perancangan CRM pada Toko Buku Gapura

4. Diagram Nol

Diagram Nol merupakan penjabaran dari proses DFD. Berikut ini adalah gambar Diagram Nol yang telah dibangun seperti yang terlihat pada 4.2 di bawah ini :

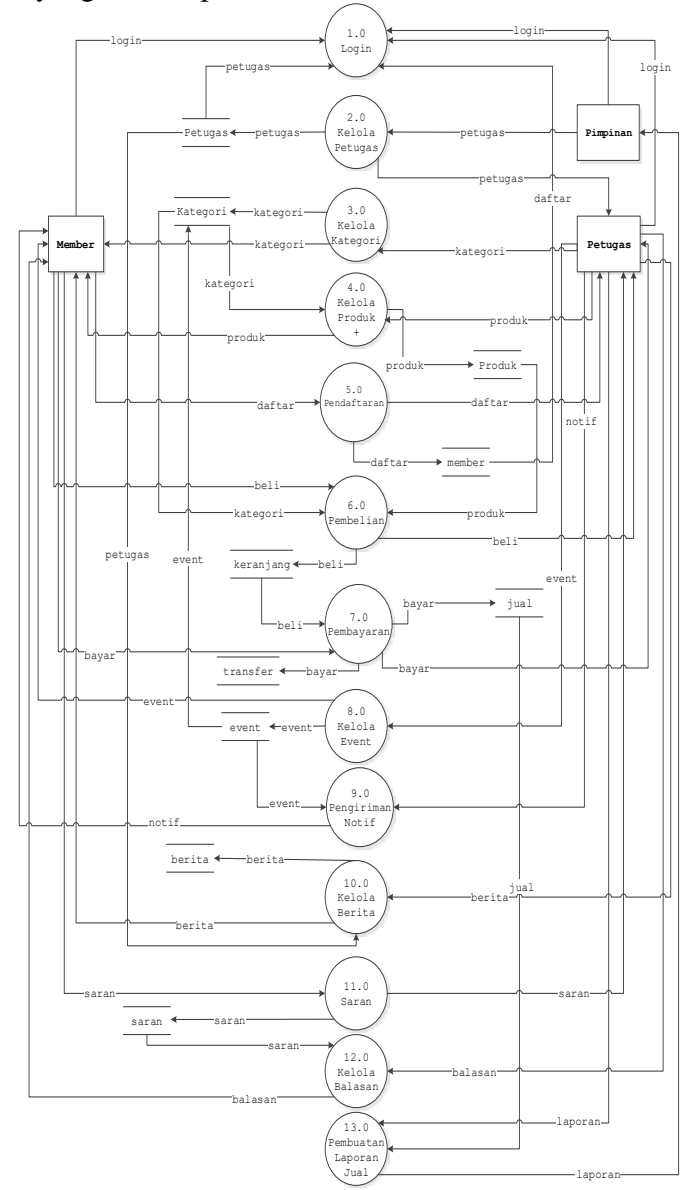

Gambar 3 Data Flow Diagram

\section{HASIL}

\section{A. Pembahasan}

Setelah dilakukan serangkaian pengujian terhadap sistem pemesanan dan penjualan dengan konsep Customer Relationship Management yang dibangun maka hasil dari pengujian sistem yang dilakukan adalah :

a. Aplikasi ini mampu memberikan informasi tentang proses pembelian barang yang terjadi di toko buku Gapura. 
b. Aplikasi ini mampu mengintegerasikan semua data yang diperoleh sehingga data yang diperoleh real atau tidak terjadinya kesalahan data dalam pembelian.

c. Admin dapat lebih mudah bertransaksi dengan pelanggan.

\section{B. Tampilan Utama}

Menu utama merupakan halaman awal padaweb toko buku Gapura. Pada halaman menu utama ini terdapat beberapa link menu yang disediakan, seperti Beranda, promo, berita, produk, daftar, masuk.

\section{Halaman Login}

Menu login merupakan tampilan awal. Bentuk tampilan form menu login dapat dilihat dalam gambar 5.22:

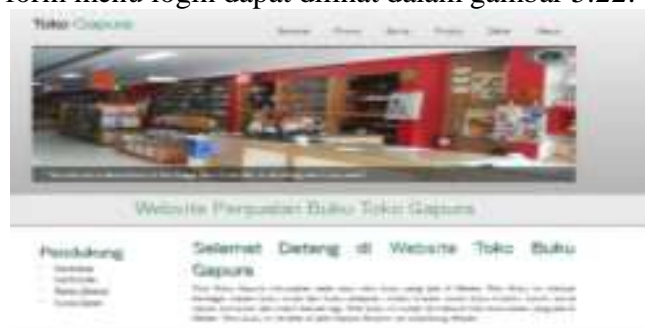

Gambar 4 Tampilan Utama

\section{Tampilan Regisrasi Member}

ini berfungsi sebagai tampilan untuk mengisi data-data sebagai member baru. Registrasi dapat dilihat pada Gambar 5.23 berikut:

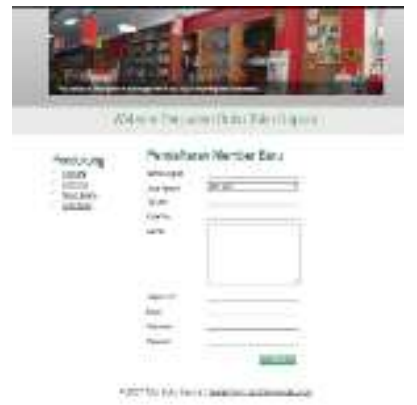

Gambar 5 Registrasi Member

\section{Tampilan Login Member}

Tampilan ini berfungsi sebagai tampilan untuk masuk ke sistem sebagai pelanggan dengan username dan password yang sudah terdaftar. Tampilan Login Member dapat dilihat pada Gambar 5.24 berikut:

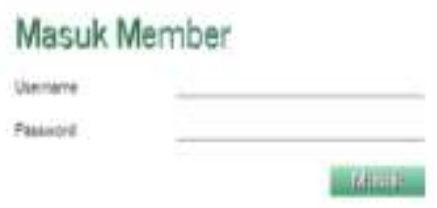

Gambar 6 Tampilan Login Member

\section{Tampilan Promo}

Tampilan ini berfungsi untuk menampilkan promo toko buku secara detail. Tampilan Promo dapat dilihat pada Gambar 5.25 berikut:

\section{Daftar Promo Kami}

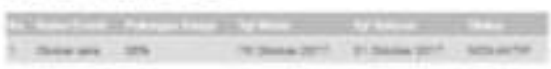

Gambar 7 Tampilan Promo

\section{Tampilan Berita}

Tampilan ini berfungsi untuk menampilkan berita terbaru secara detail. Tampilan Berita Terbaru dapat dilihat pada Gambar 5.26 berikut:

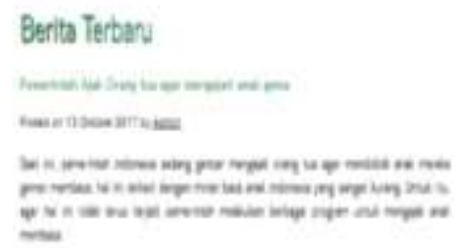

Gambar 5.26 Tampilan Berita

\section{Tampilan Produk}

Tampilan ini berfungsi untuk menampilkan produk yang tersedia. Tampilan Produk dapat dilihat pada Gambar 5.27 berikut:
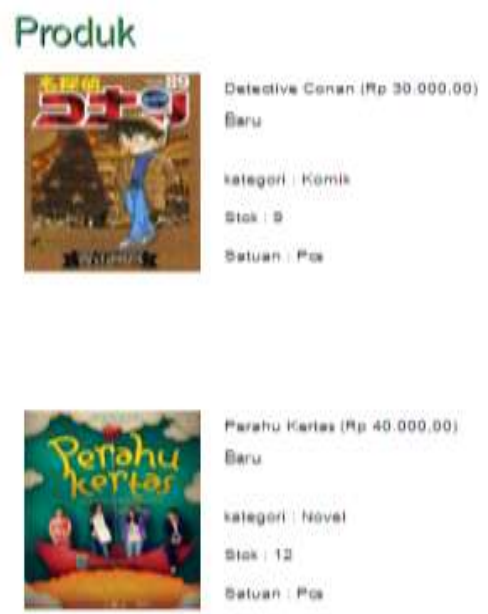

Gambar 5.27 Tampilan Daftar Produk

\section{Tampilan Belanja Produk}

Tampilan ini berfungsi untuk menampilkan detail produk yang dibelanjakan dan Pembelian Produk. Tampilan Belanja Produk dapat dilihat pada Gambar 5.28 berikut:

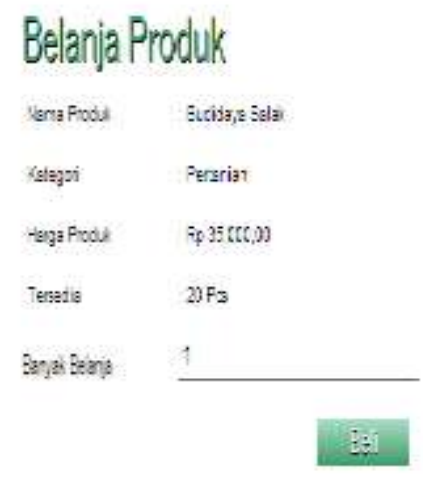

Gambar 5.28 Tampilan Belanja Produk

\section{Tampilan Keranjang Belanja}

Tampilan ini berfungsi untuk memberikan inasi produk yang akan dibeli. Keranjang Belanja dapat dilihat pada Gambar 5.29 berikut: 


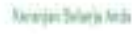

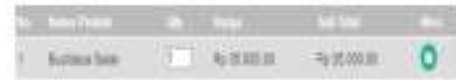 \\ Trian knowore \\ Gambar 5.29 Tampilan Keranjang Belanja}

\section{Tampilan Status Pesanan}

Tampilan ini berfungsi untuk mengecek status belanja customer. Tampilan Status Pesanan dapat dilihat pada Gambar 5.30 berikut:

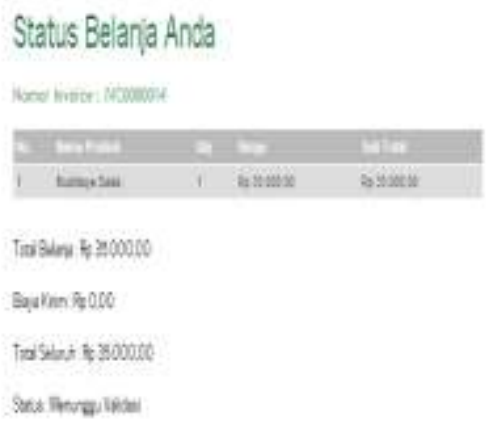

Gambar 5.30 Tampilan Status Pesanan

\section{Tampilan Konfirmasi Pembayaran}

Tampilan ini berfungsi untuk menampilkan konfirmasi pembayaran. Konfirmasi Pembayaran dapat dilihat pada Gambar 5.31 berikut:

$$
\begin{aligned}
& \text { Konfirmasi Pembayaran } \\
& \text { Nathess } \\
& \text { Ne Pshathe } \\
& \text { DiWk Trenefor } \\
& \text { Finse Fordm } \\
& \text { Hator } \\
& \text { Tonasel insto: } \\
& \text { Foro }
\end{aligned}
$$

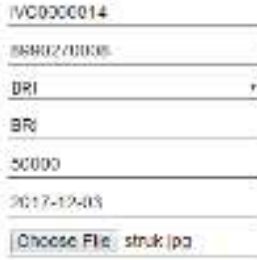

Gambar 5.31 Tampilan Konfirmasi Pembayaran

11. Tampilan History Transaksi Belanja

Tampilan ini berfungsi untuk menampilkan rekaman transaksi pembayaran member. Rekam Transaksi Belanja dapat dilihat pada Gambar 5.32 berikut:

Rekam Transaksi Belanja Anda

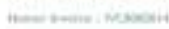

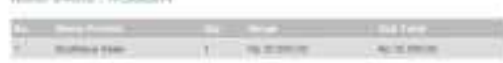

towesestateor

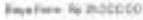

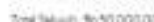

Gambar 5.32 Tampilan History Transaksi Belanja

\section{Tampilan Saran}

Tampilan ini berfungsi untuk menyampaikan kritik dan saran pada Toko Buku Gapura. Saran dapat dilihat pada Gambar 5.33 berikut:

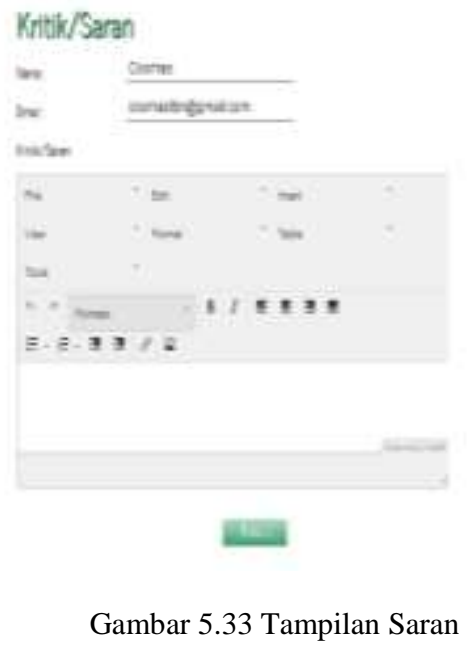

\section{Tampilan Penjualan Laporan}

Tampilan ini berfungsi untuk menampilkan laporan penjualan pada Toko Buku Gapura. Tampilan Laporan Penjualan dapat dilihat pada Gambar 5.34 berikut:

Laporan Penujalan

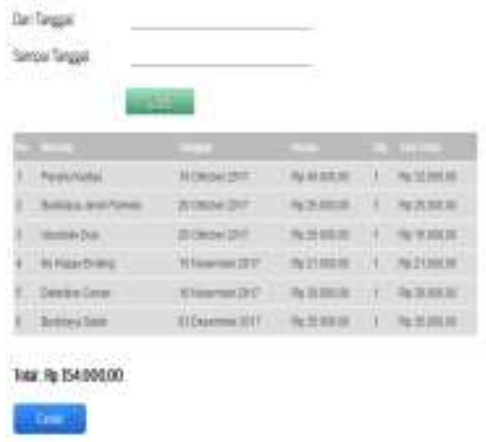

Gambar 5.34 Tampilan Laporan Penjualan

\section{KESIMPULAN}

Adapun kesimpulan dari penelitian ini antara lain:

1. Dengan adanya sistem ini, proses pemesanan dan penjualan dapat dilakukan dengan efektif dan efisien.

2. Dengan sistem ini juga pihak Toko Buku Gapura dapat memberikan laporan penjualan dan income yang cepat.

3. Dengan adanya sistem ini, pihak Toko Buku Gapura dapat memberikan layanan yang baik kepada konsumen.

\section{DAFTAR PUSTAKA}

[1] Budi Raharjo. (2011). Belajar Otodidak Membuat Database Menggunakan Bandung
MySQL. 
[2] Imam Husni Al Amin, Kristanto A (2014). Aplikasi Customer Relationship Management di CV. Matahari Digital Printing Semarang

.[3] Ladjamudin. (2013). Analisis Dan Desain Sistem Informasi. Yogyakarta: Ghara Ilmu

[4] Rita Afyenni. (2014). Perancangan Data Flow Diagram Untuk Sistem Informasi Sekolah Pada SMA Pembangunan UNP, Padang.

[5] Winda Melanta. (2014). Customer Relationship Management Dan Loyalitas Konsumen Pada PT Syapira Laras Persada. 